BIOFARM

Jurnal Ilmiah Pertanian

ISSN Print: 0216-5430; ISSN Online: 2301-6442

Vol. 16, No. 1, April 2020

\title{
Pengaruh Konsentrasi dan Interval Aplikasi Pupuk Organik Cair Urin Kelinci Terhadap Pertumbuhan dan Produksi Tanaman Wortel (Daucus carota L.)
}

\author{
The Effect Of Concentration and Interval of Aplication of Rabbit Urine Liquid \\ Organic Fertilizer on the Growth and Production of Carrots (Daucus carota L.)
}

\author{
Ahmad Solichin ${ }^{1 *}$ dan Ubad Badrudin ${ }^{1}$ \\ ${ }^{1}$ Program Studi Agroteknologi, Fakultas Pertanian, Universitas Pekalongan \\ *Korespondensi Penulis:Solichinahmad48@gmail.com
}

\begin{abstract}
ABSTRAK
Tanaman wortel merupakan sayuran yang dikenal dan digemari oleh seluruh lapisan masyarakat. Penelitian bertujuan untuk mengetahui pengaruh konsentrasi dan interval aplikasi pupuk organik cair urin kelinci dan interaksinya terhadap pertumbuhan dan produksi tanaman wortel. Penelitian menggunakan Rancangan Acak Kelompok (RAK) yang terdiri atas 2 faktor dengan ulangan 3 kali. Faktor pertama konsentrasi POC (K0=0 ml/l, K1=15 ml/l, K2=30 ml/l, K3=45 ml/l), faktor kedua interval $(11=4$ hari sekali, I2=6 hari sekali, I3=8 hari sekali). Variabel yang diamati meliputi tinggi tanaman, jumlah pelepah, jumlah daun per tanaman, panjang akar serabut, panjang umbi, diameter umbi, bobot umbi per tanaman, bobot umbi per petak, saat keluarnya umbi per tanaman, bobot brangkasan per tanaman. Data yang diperoleh dianalisis menggunakan uji $F$, jika antara faktor yang dicoba terdapat perbedaan nyata, maka analisis dilanjutkan uji BNT taraf $5 \%$. Hasil penelitian menunjukkan bahwa konsentrasi POC urin kelinci berbeda sangat nyata terhadap tinggi tanaman, jumlah pelepah, jumlah daun per tanaman, panjang akar serabut, diameter umbi, bobot umbi per tanaman, bobot umbi per petak, saat keluarnya umbi per tanaman, bobot brangkasan per tanaman, konsentrasi POC urin kelinci terbaik adalah konsentrasi $30 \mathrm{ml} / \mathrm{l}$. Interval POC urin kelinci berbeda sangat nyata terhadap tinggi tanaman, diameter umbi, bobot umbi per tanaman. Interval POC urin kelinci terbaik adalah interval 4 hari sekali. Interaksi antara konsentrasi dan interval aplikasi POC urin kelinci berbeda sangat nyata terhadap tinggi tanaman, panjang akar serabut, diameter umbi, bobot umbi per tanaman. Interaksi terbaik konsentrasi $30 \mathrm{ml} / \mathrm{l}$ dan interval 4 hari sekali.
\end{abstract}

Kata kunci: Wortel, konsentrasi, interval POC

\begin{abstract}
Carrots are vegetables that are well known and favored by anybody from all walks of life. This research aims to determine the effect of concentration and application interval of rabbit urine liquid fertilizer and interactions on growth and production of carrot plants. This research used randomized block design which consists of 2 factors with 3 replications. The first factor was the concentration of liquid organic fertilizer (control, $K 1=15 \mathrm{ml} / \mathrm{l}, K 2=30 \mathrm{ml} / \mathrm{l}, K 3=45 \mathrm{ml} / \mathrm{l})$, meanwhile the second factors are is the interval ( $11=4$ days, $12=6$ days, 13 once every 8 days). The observed variables were plant height, number of midribs, number of leaves in each plant, fibrous root length, tuber length, tuber diameter, tuber weight in each plant, tuber weight in each plot, when the plant tuber was released, and crop stover weight. The data obtained were analyzed using the $F$ test, if there were significant differences found between the factors, then the analysis continued with a LSD test level of $5 \%$. The results showed that the rabbit urine liquid organic fertilizer concentration was significantly different from plant height, number of midribs, number of leaves in each plant, fibrous root length, tuber length, tuber diameter, tuber weight in each plant, tuber weight in each plot, when the plant tuber was released, crop stover weight. The best concentration of rabbit urine liquid organic fertilizer was the concentration of $30 \mathrm{ml}$. The rabbit urine liquid organic fertilizer interval was significantly different from plant height, tuber diameter, and tuber height in each plant. The best organic liquid urine rabbit urine interval was once every 4 days. The interaction between the concentration and the interval of application of rabbit urine liquid organic fertilizer was significantly different from plant height, fibrous root length, tuber diameter, tuber weight in each plant. The best interactions are concentrations of $30 \mathrm{ml} / /$ and the interval was once every 4 days.
\end{abstract}

Keywords: Carrot, Concentration, Interval of liquid organic fertilizer

\section{PENDAHULUAN}

Selada (Lactuca sativa L.) merupakan tanaman yang berasal dari Asia Barat kemudian menyebar di Asia dan negaranegara beriklim sedang dan panas. Tanaman selada dapat tumbuh baik di dataran tinggi maupun rendah. Selada juga dapat tumbuh baik pada berbagai jenis tanah (Sugeng, 1983). Menurut Pracaya (2011) bertanam selada itu mudah selama tersedia bahan organik pada tanah dan cukup sinar matahari serta tidak tergenang air. Cahyono (2005) menyatakan bahwa selada memliki nilai 
ekonomis yang sangat tinggi setelah kubis krop, kubis bunga dan brokoli. Konsumennya mulai dari kalangan masyarakat kelas bawah hingga masyarakat kelas atas. Hal tersebut menunjukan dari aspek sosial bahwa masyarakat Indonesia mudah menerima kehadiran selada untuk konsumsi sehari-hari (Haryanto dkk., 1995).

Masyarakat Indonesia pada tahun 2005 sebanyak 219,8 juta jiwa, pada tahun 2007 meningkat menjadi 225,6 juta jiwa dan diperkirakan penduduk Indonesia berjumlah 248,8 juta jiwa pada tahun 2013. Hal ini berbanding lurus dengan tingkat konsumsi sayuran yang terus meningkat, berdasarkan Departemen Pertanian konsumsi sayur di Indonesia pada tahun 2005 sebesar 35,30 $\mathrm{kg} / \mathrm{kapita} / \mathrm{tahun}$, kemudian dan tahun 2007 meningkat sebesar 40,90 kg/kapita/tahun dan diperkirakan pada tahun 2013 kebutuhan sayuran mencapai $57.664 \mathrm{~kg} / \mathrm{kapita} /$ tahun. Akan tetapi kebutuhan yang tinggi tidak diimbangi dengan banyaknya produksi sayuran dilihat dari total impor khususnya selada pada tahun 2013 mencapai 160.581 $\mathrm{kg}$. Kurangnya produksi sayuran disebabkan beralihnya fungsi lahan pertanian menjadi lahan pemukiman mengingat semakin pesatnya pembangunan di Indonesia (Badan Pusat Statistik, 2015).

Salah satu faktor penting yang dapat mempengaruhi pertumbuhan dan rendahnya produksi selada adalah ketersediaan unsur hara. Unsur hara dapat ditingkatkan ketersediaanya dalam tanah dengan memperbaiki kondisi tanah melaui pemupukan. Di dalam tanah memang sudah tersedia makanan secara alamiah, namun tidak semua tanah menyediakan makanan yang cukup untuk tanaman. Tanah yang tidak menyediakan makanan perlu dibantu dengan menambah kadar makanan didalam tanah, yaitu dengan memberikan pupuk.

Media tumbuh yang baik harus memiliki sifat fisik, kimia, dan biologi, yang baik, memiliki unsur hara yang cukup, bertekstur ringan serta dapat menahan air sehingga menciptakan kondisi yang dapat menunjang pertumbuhan tanaman. Media tanam sangat berperan penting dalam mendukung pertumbuhan tanaman. Media tanam berfungsi untuk membantu tanaman berdiri tegak dan mencukupi kebutuhan air serta unsur hara yang diserap oleh akar-akarnya. Chuhairy dan Sitanggang (2005) menyatakan bahwa media tanam yang baik untuk perbanyakan tanaman pada prinsipnya adalah harus memiliki sifat: (1) porous atau drainasenya baik, sehingga mudah membuang kelebihan air dan mudah memadat, (2) kaya bahan organik, (3) memiliki $\mathrm{pH}$ netral $(6,5)$ atau sedikit basa $(\mathrm{pH}$ 7-7,5).

Untuk meningkatkan pertumbuhan dan hasil tanaman selada yang tumbuh di dataran rendah, diperlukan media tanam yang tepat serta ketersediaan unsur hara yang cukup. Menurut Rukmana (2007), faktor penting yang perlu diperhatikan dalam meningkatkan produksi selada adalah dengan mencukupi ketersediaan unsur hara. Salah satu cara untuk memenuhi kebutuhan hara tanaman selada dengan menggunakan pupuk organik cair (POC).

Menurut Hadisuwito (2011), pupuk organik cair adalah larutan darihasil pembusukan bahan-bahan organik yang berasal dari sisa tanaman, kotoran hewan dan manusia yang kandungan unsur haranya lebih dari satu unsur. Keuntungan POC adalah dapat menyediakan hara makro dan mikro, tidak merusak struktur tanah meskipun seringkali ginukan, memiliki sifat higrokofisitas (mudah larut) sehingga bisa langsung digunakan dengan tidak membutuhkan interval waktu yang lama untuk diserap oleh tanaman (Parnata, 2010). Salah satu bahan yang dapat digunakan untuk POC adalah limbah cair kotoran ternak yaitu urin. Faktor yang perlu diperatikan dalam pemberian POC adalah konsentrasi yang tepat. Semakin tinggi konsentrasi pupuk yang diberikan maka kandungan unsur hara yang diterima oleh tanaman akan semakin tinggi, begitu pula semakin sering frekuensi aplikasi pupuk daun yang dilakukan pada tanaman, maka kandung unsur hara juga semakin tinggi. Namun pemberian konsentrasi yang berlebihan justru akan melibatkan timbulanya gejala kelayuan pada tanaman (Suwandi dan Nurtika, 1987).

\section{METODE PENELITIAN}

Penelitian dilaksanakan di Desa Kadilangu, Kecamatan Batang, Kabupaten Batang dengan ketinggian tempat \pm 15 meter di atas permukaan laut (m dpl) pada bulan November sampai dengan Desember 2019. Rancangan yang digunakan adalah Rancangan Acak Kelompok Lengkap (RAKL) dengan perlakuan faktorial $3 \times 4$. Faktor pertama Macam media tanam (M) yang terdiri atas tiga taraf, yaitu tanah : arang sekam : pupuk kandang dengan perbandingan 2:1:1 (M1), 1:2:1 (M2), dan 1:1:2 (M3). Faktor kedua adalah Konsentrasi 
POC urin kelinci $(\mathrm{K})$ yang terdiri atas empat taraf, yaitu tanpa konsentrasi POC (K0), konsentrasi POC $1 \mathrm{ml} /$ liter (K1), konsentrasi POC $2 \mathrm{ml} /$ iter (K2) dan konsentrasi POC 3 $\mathrm{ml} /$ liter (K3). Dengan demikian terdapat 12 kombinasi, masing-masing kombinasi diulang 3 kali sehingga ada $(4 \times 3) \times 3=36$ satuan percobaan.

Data yang diperoleh dianalisis dengan uji $F$, jika antara faktor yang dicoba terdapat perbedaan nyata, maka analisis dilanjutkan dengan uji BNT, kedua factor perlakuan diuji dengan uji kontras orthogonal. variabel yang diamati meliputi: tinggi tanaman $(\mathrm{cm})$, jumlah daun (helai), luas daun terluas ( $\mathrm{cm} 2)$, berat segar daun per tanaman (g), jumlah akar (buah), panjang akar terpanjang $(\mathrm{cm})$, berat segar akar $(\mathrm{g})$, volume akar $(\mathrm{ml})$, berat kering akar (g) dan berat segar brangkasan (g).

\section{HASIL DAN PEMBAHASAN}

\section{Pengaruh Komposisi media tanam}

Hasil penelitian menunjukkan bahwa komposisi media tanam berbeda sangat nyata terhadap variabel tinggi tanaman, luas daun terluas, berat segar daun per tanaman, jumlah akar, volume akar, berat kering akar dan berat segar brangkasan. Hasil terbaik dicapai pada perlakuan komposisi media tanam tanah : arang sekam : pupuk kandang dengan perbandingan 1:1:2. Hal ini karena kombinasi media tanam antara tanah dengan arang sekam dan pupuk kandang yang merupakan bahan organik pada tingkat takaran dan perbandingan yang sesuai akan menciptakan aerasi serta drainase yang baik. Hal tersebut akan memungkinkan hara yang terdapat dalam media tanam dapat dimanfaatkan dengan baik oleh tanaman (Hali dan Telan, 2018).

Augustien dan Suhardjono (2017), mengemukakan media tanam yang baik harus mempunyai sifat fisik yang baik, lembab, berpori dan memiliki draenase yang baik. Media tanah memiliki pori-pori mikro yang lebih banyak dari pada pori-pori makro, sehingga tanah memiliki kemampuan untuk mengikat air yang cukup kuat. Media arang sekam berperan penting dalam perbaikan struktur tanah karena karakteristiknya yang ringan, kapasitas menahan air yang tinggi, berwarna hitam sehingga dapat mengabsorbsi sinar matahari dengan baik. Arang sekam juga memiliki porositas yang baik dan kemampuan menyerap air rendah. Pemberian pupuk kandang dapat memperbaiki struktur tanah, memper-tahankan kadar bahan organik, dan sebagai sumber zat makanan bagi tanaman.

Tabel 1. Angka rata-rata dan Analisis Statistik Data Penelitian Pengaruh Komposisi media tanam dan Konsentrasi POC Urin Kelinci

\begin{tabular}{|c|c|c|c|c|c|}
\hline Perlakuan & $\begin{array}{l}\text { Tinggi } \\
\text { Tanaman } \\
\text { (cm) }\end{array}$ & $\begin{array}{l}\text { Jumlah } \\
\text { Daun } \\
\text { (helai) }\end{array}$ & $\begin{array}{l}\text { Luas } \\
\text { Daun } \\
\text { Terluas } \\
\text { (cm2) }\end{array}$ & $\begin{array}{c}\text { Berat } \\
\text { Segar } \\
\text { Daun } \\
(\mathrm{g})\end{array}$ & $\begin{array}{c}\text { Jumlah } \\
\text { Akar } \\
\text { (buah) }\end{array}$ \\
\hline \multicolumn{6}{|l|}{$\begin{array}{l}\text { Komposisi media tanam (Tanah } \\
\text { Arang Sekam : Pupuk Kandang) }\end{array}$} \\
\hline$M 1=2: 1: 1$ & $31,65 a$ & 9,22 & $93,62 a$ & $25,27 a$ & $45,33 a$ \\
\hline$M 2=1: 2: 1$ & $33,57 a b$ & 9,78 & $104,53 b$ & $26,65 b$ & $48,27 \mathrm{~b}$ \\
\hline$M 3=1: 1: 2$ & $34,1 b$ & 10,15 & $131,35 c$ & $28,8 \mathrm{c}$ & $52,8 \mathrm{c}$ \\
\hline \multicolumn{6}{|l|}{ Konsentrasi POC } \\
\hline $\mathrm{K} 0=0 \mathrm{ml} / \mathrm{l}$ & $24,42 a$ & 9,11 & $54,28 a$ & $18,93 a$ & $35,82 a$ \\
\hline $\mathrm{K} 1=1 \mathrm{ml} / \mathrm{l}$ & $31,96 b$ & 9,25 & $98,49 b$ & $23,71 b$ & $45,67 b$ \\
\hline $\mathrm{K} 2=2 \mathrm{ml} / \mathrm{l}$ & $42 c$ & 10,31 & $171,74 d$ & $37,89 d$ & $63,89 d$ \\
\hline $\mathrm{K} 3=3 \mathrm{ml} / \mathrm{l}$ & $34,04 b$ & 10,2 & $114,81 \mathrm{c}$ & $27,09 \mathrm{c}$ & $49,82 \mathrm{c}$ \\
\hline
\end{tabular}


Campuran beberapa bahan untuk media tanam harus menghasilkan struktur yang sesuai karena setiap jenis media mempunyai pengaruh yang berbeda bagi tanaman. Tanaman memerlukan kombinasi yang tepat dari berbagai nutrisi untuk tumbuh, berkembang, dan bereproduksi. Ketika tanaman mengalami malnutisi, maka ia akan menunjukkan gejala-gejala yang tidak stabil. Pada perlakuan perbandingan komposisi media tanam 2:1:1 didapatkan hasil terendah pada semua variabel pengamatan. Hal ini karena komposisi tanah yang lebih banyak dari arang sekam dan pupuk kandang menyebabkan kurangnya aerasi. Hal ini sesuai dengan pernyataan Augustien dan Suhardjono (2017) bahwa kemampuan tanah untuk menahan air yang terlalu besar mengakibatkan aerasi kurang, sehingga pertumbuhan tanaman akan terhambat.

$$
\text { Pada perlakuan perbandingan }
$$
komposisi media tanam 1:2:1, komposisi arang sekam lebih banyak dibanding tanah dan pupuk kandang sehingga pertumbuhan dan perkembangan tanaman kurang optimal. Hal ini karena arang sekam sukar terdekomposisi. Arang sekam padi memiliki kandungan lignin. Jika pada suatu media mengandung unsur lignin yang tinggi, maka keadaan seperti ini akan mengakibatkan kurangnya laju pembusukan pada media tanam yang mengakibatkan rendahnya persediaan unsur hara dan mengakibatkan pertumbuhan tanaman menjadi kurang baik (Hali dan Telan, 2018). Sejalan dengan pernyataan Kasumbogo (1997), arang sekam memiliki banyak kandungan lignin, selulosa dan hemiselulosa. Lignin merupakan senyawa organiksebagi sumber penyedia $\mathrm{C}$ organik, dan lignin juga memiliki sifat yang sulit untuk terdekomposisi sehingga belum bisa menyediakan kondisi lingkungan tumbuh yang berpengaruh pada pertumbuhan dan perkembangan tanaman.

Tabel 2. Angka rata-rata dan Analisis Statistik Data Penelitian Pengaruh Pengaruh Komposisi media tanam dan Konsentrasi POC Urin Kelinci

\begin{tabular}{|c|c|c|c|c|c|}
\hline Perlakuan & $\begin{array}{l}\text { Panjang } \\
\text { Akar } \\
\text { Terpanjang } \\
(\mathrm{cm})\end{array}$ & $\begin{array}{c}\text { Berat } \\
\text { Segar } \\
\text { Akar } \\
(\mathrm{g})\end{array}$ & $\begin{array}{l}\text { Volume } \\
\text { Akar } \\
(\mathrm{ml})\end{array}$ & $\begin{array}{c}\text { Berat } \\
\text { Kering } \\
\text { Akar } \\
(\mathrm{g})\end{array}$ & $\begin{array}{c}\text { Berat Segar } \\
\text { Brangkasan } \\
\text { (g) }\end{array}$ \\
\hline \multicolumn{6}{|c|}{$\begin{array}{l}\text { Komposisi media tanam } \\
\text { (Tanah : Arang Sekam : } \\
\text { Pupuk Kandang) }\end{array}$} \\
\hline$M 1=2: 1: 1$ & 10,98 & 3,84 & $3,35 a$ & $0,79 a$ & $39,33 a$ \\
\hline$M 2=1: 2: 1$ & 11,42 & 3,80 & $3,95 b$ & $0,84 a$ & $40,8 b$ \\
\hline$M 3=1: 1: 2$ & 12,1 & 3,91 & $4,12 b$ & $1,004 b$ & $43,05 c$ \\
\hline \multicolumn{6}{|l|}{ Konsentrasi POC } \\
\hline $\mathrm{K} 0=0 \mathrm{ml} / \mathrm{l}$ & $9,6 a$ & 3,75 & 3,73 & $0,74 a$ & $33,02 a$ \\
\hline $\mathrm{K} 1=1 \mathrm{ml} / \mathrm{l}$ & $10,98 b$ & 3,84 & 3,73 & $0,79 a b$ & $37,87 b$ \\
\hline $\mathrm{K} 2=2 \mathrm{ml} / \mathrm{l}$ & $13,8 \mathrm{c}$ & 4,04 & 4,09 & $1,12 \mathrm{c}$ & $52,09 d$ \\
\hline $\mathrm{K} 3=3 \mathrm{ml} / \mathrm{l}$ & $11,62 b$ & 3,78 & 3,67 & $0,87 \mathrm{cb}$ & $41,27 \mathrm{c}$ \\
\hline
\end{tabular}

Pada perlakuan perbandingan komposisi media tanam 1:1:2 memberikan hasil tertinggi pada semua variabel pengamatan. Hal ini dikarenakan komposisi media tanam dengan perbandingan tersebut telah sesuai dengan kebutuhan tanaman untuk melakukan proses fisiologisnya. Komposisi pupuk kandang yang lebih banyak dari tanah dan arang sekam diduga dapat menyediakan unsur hara untuk memacu pertumbuhan tanaman selada serta bahan organik yang mampu memperbaiki struktur tanah. Sesuai dengan pernyataan Hartatik dan Widowati (2010), penambahan bahan organik sebagai teknologi produksi pada tanaman tidak hanya meningkatkan hasil tanam, tetapi juga memperbaiki kesuburan tanah. Tanah yang subur dan banyak 
mengandung bahan organik dapat memberikan produktivitas yang optimal bagi pertumbuhan dan perkembangan tanaman.

\section{Pengaruh Konsentrasi POC Urine Kelinci}

Hasil penelitian menunjukkan bahwa konsentrasi POC urine kelinci berbeda sangat nyata terhadap variabel tinggi tanaman, luas daun terluas, berat segar daun per tanaman, jumlah akar, panjang akar terpanjang, berat kering akar dan berat segar brangkasan. Hasil terbaik dicapai pada perlakuan konsentrasi POC $2 \mathrm{ml} / \mathrm{l}$. Hal ini dikarenakan pemberian POC dengan konsentrasi $2 \mathrm{ml} / \mathrm{l}$ merupakan konsentrasi yang optimal untuk pertumbuhan tanaman selada. Hal ini sejalan dengan dengan pendapat Leiwakabessy (1988) yang menyatakan bahwa, pertumbuhan tanaman sangat ditentukan oleh unsur hara yang tersedia dalam keadaan optimum dan seimbang.

Penambahan ketersediaan unsur hara pada tanaman selada didapat dari urin kelinci.
Urin kelinci mengandung nitrogen yang sangat tinggi, disebabkan karena kelinci lebih banyak mengkonsumsi tanaman hijauan. Urin kelinci memiliki kandungan unsur Nitrogen $(\mathrm{N})$, Phosfor $(\mathrm{P})$, Kalium $(\mathrm{K})$ yang lebih tinggi $(2.72 \%, 1.1 \%$, dan $0,5 \%)$ dibandingkan dengan Urin ternak lainnya seperti sapi yaitu $\mathrm{N}(0,5 \%), \mathrm{P}(0,2 \%)$ dan $\mathrm{K}$ $(0,5 \%)$ sedangkan pada domba yaitu $\mathrm{N}$ $(1,50 \%), P(0,33 \%)$ dan K $(1,35 \%)$ (Karo, 2014).

Peranan utama $\mathrm{N}$ dalam tanaman adalah sebagai unsur penyusun protein dan merupakan unsur dalam molekul klorofil. Unsur $\mathrm{P}$ dalam tanaman berperan dalam transfer energi, $P$ diubah dalam bentuk ATP. ATP dibutuhkan sebagai sumber energi untuk berbagai reaksi sistesis biokimia, seperti sintesis lipida, pati, dan protein. Unsur $\mathrm{K}$ dapat meningkatkan turgor sel pada titik-titik tumbuh dan bertanggung jawab dalam membuka dan metupnya stomata (Samekto, 2008).

Tabel 3. Angka rata-rata Interaksi Penelitian Pengaruh Pengaruh Pengaruh Komposisi Media Tanam dan Konsentrasi POC Urin Kelinci

\begin{tabular}{cccccc}
\hline Perlakuan & $\begin{array}{c}\text { Luas Daun } \\
\text { Terluas } \\
(\mathrm{cm} 2)\end{array}$ & $\begin{array}{c}\text { Berat Daun } \\
\text { Per } \\
\text { Tanaman } \\
(\mathrm{g})\end{array}$ & $\begin{array}{c}\text { Jumlah Akar } \\
\text { (buah) }\end{array}$ & $\begin{array}{c}\text { Berat } \\
\text { Kering Akar } \\
(\mathrm{g})\end{array}$ & $\begin{array}{c}\text { Berat Segar } \\
\text { Brangkasan } \\
(\mathrm{g})\end{array}$ \\
\hline M1K0 & $52,88 \mathrm{~b}$ & $19,73 \mathrm{c}$ & $33 \mathrm{a}$ & $0,68 \mathrm{a}$ & $32,2 \mathrm{a}$ \\
M1K1 & $95,48 \mathrm{e}$ & $20,73 \mathrm{~d}$ & $35,93 \mathrm{~b}$ & $0,75 \mathrm{bc}$ & $33,07 \mathrm{~b}$ \\
M1K2 & $140,83 \mathrm{~h}$ & $34,27 \mathrm{~h}$ & $38,53 \mathrm{c}$ & $0,90 \mathrm{f}$ & $33,8 \mathrm{c}$ \\
M1K3 & $85,28 \mathrm{~d}$ & $26,33 \mathrm{f}$ & $42,53 \mathrm{~d}$ & $0,84 \mathrm{de}$ & $34,8 \mathrm{~d}$ \\
M2K0 & $46,30 \mathrm{a}$ & $18,13 \mathrm{a}$ & $45,87 \mathrm{e}$ & $0,73 \mathrm{~b}$ & $38,27 \mathrm{e}$ \\
M2K1 & $88,96 \mathrm{~d}$ & $24 \mathrm{e}$ & $48,4 \mathrm{f}$ & $0,80 \mathrm{~cd}$ & $40,4 \mathrm{f}$ \\
M2K2 & $158,75 \mathrm{i}$ & $37,07 \mathrm{i}$ & $48,6 \mathrm{f}$ & $1 \mathrm{~g}$ & $40,53 \mathrm{f}$ \\
M2K3 & $124,11 \mathrm{~g}$ & $27,4 \mathrm{~g}$ & $49,33 \mathrm{f}$ & $0,85 \mathrm{e}$ & $41,53 \mathrm{~g}$ \\
M3K0 & $63,67 \mathrm{c}$ & $18,93 \mathrm{~b}$ & $51,73 \mathrm{~g}$ & $0,81 \mathrm{de}$ & $41,7 \mathrm{~g}$ \\
M3K1 & $111,02 \mathrm{f}$ & $26,4 \mathrm{f}$ & $57,4 \mathrm{~h}$ & $0,82 \mathrm{de}$ & $48,33 \mathrm{~h}$ \\
M3K2 & $215,65 \mathrm{j}$ & $42,33 \mathrm{j}$ & $61,93 \mathrm{i}$ & $1,45 \mathrm{~h}$ & $51,2 \mathrm{i}$ \\
M3K3 & $135,06 \mathrm{~h}$ & $27,53 \mathrm{~g}$ & $72,33 \mathrm{j}$ & $0,93 \mathrm{f}$ & $56,73 \mathrm{j}$ \\
\hline
\end{tabular}

Keterangan : Angka yang diikuti huruf yang sama pada kolom dan baris menunjukkan tidak berbeda nyata menurut uji BNT taraf $5 \%$

Selain itu dijelaskan oleh Prihmantoro (2007) bahwa nitrogen diperlukan tanaman untuk merangsang pertumbuhan tanaman, terutama batang, cabang, dan daun. Fosfor diperlukan tanaman untuk merangsang akar, khususnya akar benih dan tanaman muda. Kalium diperlukan tanaman untuk memperkuat tubuh tanaman agar tanaman tidak mudah roboh serta bunga dan buah tidak mudah gugur.

Hasil penelitian menunjukkan bahwa pertumbuhan dan hasil tanaman selada menurun pada konsentrasi $3 \mathrm{ml} / \mathrm{l}$, hal ini diduga karena penggunaan pupuk yang berlebihan dapat menyebabkan laju pertumbuhan tanaman terhambat. Harjadi 
(1993) menyatakan bahwa pemberian pupuk yang berlebihan akan menyebabkan keracunan bagi tanaman dan mengakibatkan terhambatnya laju pertumbuhan tanaman bahkan jika dalam keadaaan terus berlanjut akan mengakibatkan kematian tanaman.

Pertumbuhan tanaman selada terendah terdapat pada konsentrasi $0 \mathrm{ml} / \mathrm{l}$ (kontrol) karena unsur hara yang tersedia tidak mencukupi kebutuhan tanaman untuk melaksanakan proses metabolisme sehingga pertumbuhan tanaman terhambat. Hal ini sejalan dengan pendapat Sutejo dan Kartasapoetra (1995) yang menyatakan bahwa, kekurangan unsur hara makro dan mikro pada tanaman dapat mengakibatkan hambatan bagi pertumbuhan dan perkembangan tanaman. Kebutuhan pupuk bagi tanaman bukan hanya pada jenis unsur haranya, tetapi juga terjadi peningkatan dalam jumlah yang harus diberikan untuk mempertahankan produktifitas tanaman karena kebutuhan unsur hara semakin bertambah sejalan dengan bertambahnya umur tanaman tersebut (Sutarpradya, 1994).

\section{Pengaruh Interaksi Komposisi media tanam dan Konsentrasi POC Urine Kelinci}

Hasil analisis statistik menunjukkan bahwa interaksi antara komposisi media tanam dengan konsentrasi POC urine kelinci berpengaruh sangat nyata terhadap luas daun terluas, berat segar daun, jumlah akar, berat kering akar dan berat segar brangkasan. Kombinasi terbaik dicapai pada komposisi media tanam tanah, arang sekam dan pupuk kandang dengan perbandingan 1:1:2 dan konsentrasi POC urine kelinci 2 $\mathrm{ml} / \mathrm{l}$ (M3K2).

Hal ini menunjukkan komposisi media tanam dan pemberian konsentrasi POC dapat menunjang pertumbuhan dan perkembangan tanaman.

Kosasih dan Heryati (2006) mengatakan bahwa media yang baik mempunyai empat fungsi utama, yaitu memberi unsur hara dan sebagai media perakaran, menyediakan air dan tempat penampungan air, menyediakan udara untuk respirasi akar dan sebagai tempat bertumbuhnya tanaman. Selain faktor media tanam, pemberian pupuk tambahan juga dapat menunjang pertumbuhan tanaman selada. Salah satu cara pemberian pupuk pada tanaman adalah dengan cara disemprotkan pada seluruh bagian tanaman.

Mekanisme masuknya hara melalui daun berhubungan dengan proses membuka dan menutupnya stomata. Membukanya stomata merupakan proses yang diatur oleh tekanan turgor dari sel-sel penutup. Meningkatnya tekanan turgor akan membuka lubang stomata bersama-sama dengan masuknya air. Sel-sel penting yang berperan di dalam mekanisme serapan unsur hara melalui daun adalah epidermis, sel penjaga, stomata, mesofil dan seludang pembuluh. Pupuk yang disemprotkan masuk ke dalam stomata secara difusi dan selanjutnya masuk ke dalam sel penjaga, mesofil maupun seludang pembuluh selanjutnya berperan dalam fotosintesis (Wibowo, 1998). Pemberian pupuk dengan cara disemprot juga memberikan manfaat lain yaitu bertambahnya kandungan unsur hara pada tanah karena adanya tetesan POC pada saat proses penyemprotan. Hal ini sesuai dengan pendapat Purwanti (2014) yang menyatakan meskipun penyemprotan POC ini lewat daun tapi tetesan-tesesan dari POC yang diberikan jatuh ke media tanamnya sehingga menambah unsur hara dari media tanam yang digunakan.

\section{KESIMPULAN}

Berdasarkan hasil penelitian dan pembahasan dapat diambil kesimpulan sebagai berikut.

1. Komposisi media tanam berbeda sangat nyata terhadap variabel tinggi tanaman, luas daun terluas, berat segar daun per tanaman, 
jumlah akar, volume akar, berat kering akar dan berat segar brangkasan serta tidak berbeda nyata pada variabel jumlah daun, panjang akar terpanjang dan berat segar akar. Komposisi media tanam yang terbaik adalah tanah:arang sekam: pupuk kandang (1:1:2) (M3).

2. Konsentrasi POC urin kelinci berbeda sangat nyata terhadap tinggi tanaman, luas daun terluas, berat segar daun per tanaman, jumlah akar, panjang akar terpanjang, berat kering akar dan berat segar brangkasan serta tidak berbeda nyata pada variabel jumlah daun, berat segar akar dan volume akar. Pertumbuhan dan produksi tanaman selada terbaik dicapai pada konsentrasi POC 2 $\mathrm{ml} / \mathrm{l}(\mathrm{K} 2)$.

3. Terdapat interaksi antara komposisi media tanam dan konsentrasi POC yaitu pada variabel luas daun terluas, berat segar daun per tanaman, jumlah akar, berat kering akar dan berat segar brangkasan. Kombinasi terbaik dicapai pada komposisi media tanam tanah:arang sekam:pupuk kandang (1:1:2) dan konsentrasi POC 2 ml// (M3K2).

\section{DAFTAR PUSTAKA}

Augustien, N., H. Suhardjono. 2017. Peranan Berbagai Komposisi Media Tanam Organik Terhadap Tanaman Sawi (Brassica juncea L.) di Polybag. Agritrop Jurnal IImu-IImu Pertanian. Fakultas Pertanian UPN Veteran, Surabaya

Cahyono, B. 2005. Teknik Budidaya dan Analisis Usahatani Selada. Aneka ilmu. Semarang.

Chuhairy, H dan M. Sitanggang. 2005. Petunjuk Praktis Perawatan Adenium. Agromedia Pustaka, Jakarta
Hadisuwito, S. 2011. Pupuk Kompos Cair. Agromedia Pustaka. Jakarta

Hali, A., \& Telan, A. 2018. Pengaruh Beberapa Kombinasi Media Tanam Organik Arang Sekam, Pupuk Kandang Kotoran Sapi, Arang Serbuk Sabut Kelapa Dan Tanah Terhadap Pertumbuhan Dan Hasil Tanaman Terung (Solanum Melongena L.). JURNAL INFO KESEHATAN, 16(1), 83-95. https://doi.org/10.31965/infokes.V ol16.Iss1.174

Harjadi, S. S. 1993. Pengantar Agronomi. Gramedia Pustaka Utama. Jakarta.

Hartatik, W. dan L.R. Widowati, 2010. Pupuk Kandang.(online) http://www.balittanahlitbang.depta n.go. id. Diakses pada 31 Januari 2020.

Haryanto, E. T. Suhartini, dan E. Rahayu. 1995. Sawi dan Selada. Penebar Swadaya. Jakarta.

Karo. B. B., A.E. Marpaung dan A. Lasmono. 2014. Efek Tehnik Penanaman Dan Pemberian Urin Kelinci Terhadap Pertumbuhan dan Produksi Tanaman Kentang Garonala (Solanum Tuberosum L). Prosiding Seminar Nasional Sains Dan Inovasi Teknologi Pertanian. Lampung.

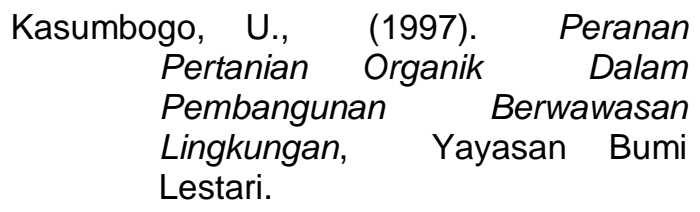

Kosasih, A, S. dan Haryati. 2006. Pengaruh Medium Sapih terhadap Pertumbuhan Bibit Shorea Selenica BL. di Persemaian. Jurnal Penelitian Hutan dan Konservasi Alam. Pusat Litbang Hutan dan Konservasi Alam. Bogor.

Leiwakabessy. $1998 . \quad P e n g e l o l a a n$ Kesuburan Tanah. Bumi Aksara. Jakarta. 
Parnata. 2010. Meningkatkan hasil panen dengan pupuk organik. Agro Media Pustaka. Jakarta.

Prihmantoro. 2007. Memupuk Tanaman Sayuran. Penebar Swadaya, Jakarta

Purwanti, H.I. 2014. Pengaruh Konsentrasi Dan Saat Pemberian Pupuk Organik Cair (POC) Berbasis Urin Kambing Terhadap Pertumbuhan Dan Produksi Tanaman Pakchoy (Brassica chinensis L.). Skripsi. Universitas Pekalongan

Rukmana, R. 2007. Bertanam Petsai dan Sawi. Penerbit Kanisius. Yogyakarta
Samekto, R. 2008. Pemupukan. PT Intan Sejati. Klaten.

Sugeng. 1983. Budidaya Tanaman Sayursayuran. Penebar Swadaya, Jakarta.

Sutarpradya. 1994. Pupuk dan Pemupukan. Pustaka Buana. Bandung.

Sutedjo, M.M dan Kartasapoetra, A.G. 1995. Pupuk dan Cara Pemupukan. Rieneka Cipta. Jakarta.

Suwandi dan Nurtika. 1987. Pengaruh pupuk biokimia "Sari Humus" pada tanaman kubis. Buletin Penelitian Hortikultura 15: 213-218.

Wibowo, G. 1998. Dasar-Dasar Fisiologi Tanaman. Suryandra Utama. Semarang. 